\title{
Early detection and personalized treatment in oral cancer: the impact of omics approaches
}

Ilda Patrícia Ribeiro ${ }^{1,2}$, Leonor Barroso ${ }^{3}$, Francisco Marques $^{4,5}$, Joana Barbosa Melo ${ }^{1,2}$ and Isabel Marques Carreira ${ }^{1,2^{*}}$

\begin{abstract}
Background: Oral cancer is one of the most common malignant lesions of the head and neck. This cancer is an aggressive and lethal disease with no significant improvements in the overall survival in the last decades. Moreover, the incidence of oral HPV-positive tumors is rising, especially in young people. This oral neoplasm develops through numerous molecular imbalances that affect key genes and signaling pathways; however, the molecular mechanisms involved in the pathogenesis and progression of oral tumors are still to be fully determined. In order to improve the quality of life and long-term survival rate of these patients, it is vital to establish accurate biomarkers that help in the early diagnosis, prognosis and development of target treatments. Such biomarkers may possibly allow for selection of patients that will benefit from each therapy modality, helping in the optimization of intensity and sequence of the treatments in order to decrease side effects and improve survival.

Conclusion: In this review we discuss the current knowledge of oral cancer and the potential role of omics approaches to identify molecular biomarkers in the improvement of early diagnosis, treatment and prognosis. The pursuit to improve the quality of life and decrease mortality rates of the oral patients needs to be centralized on the identification of critical genes in oral carcinogenesis. Understanding the molecular biology of oral cancer is vital for search new therapies, being the molecular-targeted therapies the most promising treatment for these patients.
\end{abstract}

Keywords: Oral cancer, Early diagnosis, Omics data, Molecular biomarkers, Molecular profiling

\section{Background}

Oral cancer is part of a group of cancers named head and neck cancer (HNC), which enclose a wide set of diverse tumor types arising from various anatomic structures, such as oral cavity, oropharynx, larynx, hypopharynx and nasopharynx. Histopathologically, squamous cell carcinomas (SCCs) represent nearly $90 \%$ of all these tumors and over $50 \%$ arise in the oral cavity [1]. The most significant and well-established risk factors related to this neoplasm are tobacco use (smoked or chewed), excessive alcohol consumption and/or human papilomavirus (HPV) infection. HPV genomic DNA is present in almost $25 \%$ of oral squamous cell carcinomas (OSCCs)

\footnotetext{
* Correspondence: citogenetica@fmed.uc.pt; icarreira@fmed.uc.pt ${ }^{1}$ Cytogenetics and Genomics Laboratory, Faculty of Medicine, University of Coimbra, Polo Ciências da Saúde, Coimbra 3000-354, Portugal

${ }^{2}$ CIMAGO - Center of Investigation on Environment Genetics and Oncobiology - Faculty of Medicine, University of Coimbra, Coimbra 3000-354, Portugal

Full list of author information is available at the end of the article
}

[2,3] and patients with HPV-positive oropharyngeal tumors have a better prognosis compared with HPVnegative oropharyngeal patients, although the reasons for this are not yet complete clarified [4]. It could be related to the more frequent HPV positivity in individuals having no other risk factors and to their usually different histology (poorly differentiated, basaloid) [2].

Worldwide, oral and pharyngeal tumors, when combined, represent the sixth most common cancer, with more than 300,000 estimated new cases and approximately 145,000 deaths from oral cavity cancer (including lip cancer) in 2012 [5]. Furthermore, it is estimated that its incidence will raise due to population growth, aging and the adoption of a lifestyle associated to cancer-risk factors [6]. It is interesting to note that two types of behavior and wariness have apparently contributed in opposite ways: in one way a slight decrease has been observed in the overall incidence of these tumors in the past two decades [2], which is most probably associated 
with a reduction in the prevalence of smoking [7]; on the other hand, an increase has been detected especially in oropharyngeal cancers (base of tongue and tonsillar) [8], which can be associated with the increase in oral and oropharyngeal HPV infections [7,9]. Since oral cancer has been more common in men than in women HPV vaccination for both genders should be an option to be considered regarding HNC prevention, but further studies are needed to determine the efficacy and cost-benefit of this kind of vaccination program. Although the median age for head and neck cancer diagnosis is around 60 years, it should be noted that an increase of these tumors has been described in younger patients, i.e. less than 40 years old, mainly with HPVassociated oropharyngeal cancer $[10,11]$.

Despite technological advances and improvements in OSCC diagnosis and treatment modalities, its 5-years survival rate stays low, around $50-60 \%$ [12]. This discrepancy can be explained both by the delay in the diagnosis and by the relatively high tumor recurrence rates detected in these patients. In general, at the time of diagnosis, only one third of OSCC patients have the disease at early-stages (I and II) [13].

The understanding about the biology and pathology of oral carcinogenesis process is still slow. Therefore, a better insight concerning oral cancer proliferation, invasion and cellular migration is clearly needed. This understanding is crucial to search and establish molecular targets to help in the early diagnosis, to predict the prognosis and also to direct the development of new therapeutic strategies. The purpose of this review is to provide a critical analysis of the current knowledge of oral cancer and to discuss the potential translation to clinical practice of molecular signatures using the emergent omic approaches.

\section{Diagnosis and treatment: clinical features}

Diagnosing tumors in the oral cavity might be challenging. The inspection and examination of the oral cavity has an easy access and is simple to perform; however, benign lesions can sometimes mimic the alterations observed in cancer development [14]. Additionally, the potential malignant lesions and cancer in the early stage are very subtle in the clinical appearance, which complicates the early diagnosis and treatment. Moreover, presently, there is no prognostic model devised to accurately predict the risk of OSCC patients recur after the primary treatment. Histopathology is still used as a gold standard for characterization and classification of solid tumors; however, this classification of tumors is often not satisfactory to predict the clinical outcome in individual cases [15]. The disease stage attributed at the diagnosis remains the most important prognostic indicator for OSCC. Thus, the 5-year survival rate for cancers in stage I is almost $80 \%$, while for stage IV cancers, this rate decreases to almost $20 \%$ [16].
The first-line treatment for OSCC has been surgery, which may be followed by chemo/radiotherapy. Surgery is a debilitating and considerably morbid procedure that impairs the patients' quality of life as it implies drastic alterations in chewing, swallowing, speech or facial esthetics [17]. A great dilemma for physician is delimiting the exact area of excision [18], because the presence of the tumor in or close to the surgical margin might be indicative of the risk of relapse, which influences the decision of additional treatment. Unfortunately, relapses have been observed in patients with histological tumorfree margins after surgery.

The use of Cetuximab, a monoclonal antibody targeting the extracellular ligand binding domain of the epidermal growth factor receptor (EGFR), combined with radiotherapy is approved for the treatment of locoregionally advanced HNC [19], and for the treatment of recurrent or metastatic disease in combination with platinum-based chemotherapy [20]. The introduction of Cetuximab (Erbitux ${ }^{\circ}$ in the clinical practice was a great advance in the field of targeted drugs. However, not all patients treated with Cetuximab respond well to therapy due to primary or acquired resistance, limiting significantly the clinical benefit of this drug [21]. Besides Cetuximab there are other molecular targeted agents that have been investigated for OSCC therapy.

The introduction of immune checkpoint inhibitors into HNC treatment has been explored, being the cosignaling of the programmed cell death protein 1 (PD-1) and its ligand (PD-L1) one of the major pathways of interest. PD-1 is a co-inhibitory receptor, since the ligation of PD-L1 or PD-L2 to PD-1 inhibits T-cell proliferation and down regulates expression of the anti-apoptotic molecule $\mathrm{Bcl}-\mathrm{xL}$, cytokine expression and the mTOR pathway in immune cells [22-24]. Currently, there are several anti-PD-1 and anti-PD-L1 monoclonal antibodies in clinical trials, which presenting early promising results regarding survival benefit in metastatic/recurrent HNC [25]. Due to the manifold tumor evasion strategies and different response rates for treatments, combinational therapies are crucial to treat oral cancer. Thus, adding immunotherapeutics to standard Cetuximab-containing regimens is under investigation [26].

An apparently problem in this field of targeted therapies seems to be the identification of biomarkers that help in the selection of eligible patients to benefit these expensive treatments [27], which reinforce the need of well designed studies in order to select the patients and therefore the drug according to their molecular profile.

\section{Omics in oral cancer}

Emerging OSCC omics data hold great promise for understanding of the oral carcinogenesis process, predicting prognosis and helping in the development of targeted 
therapies. Advances in the powerful omics technologies: genomics, epigenomics, transcriptomics, proteomics, metabolomics and lipidomics are opening new routes towards biomarker discovery in order to allow early diagnose and to differently discriminate the behavior of each tumor, providing personalized therapies for the patients. Considering the multifactorial nature of OSCC it is mandatory to combine different biomarkers that could lead to the implementation of prophylactic screening programs, decreasing the incidence and mortality and increase the quality of life of these patients. It is important to note that in omics technology, bioinformatics tools are required to extract relevant information from the complex huge amount of data and identify players in cancer pathways. Indeed, in this post-genomic era several questions remain to be addressed. The central question for oral oncology research seems to be the following: which alterations are likely to occur early in oral cancer, and how do these molecular imbalances thus affect the clinical outcome of the patients? It is very difficult to explain the different outcomes for patients with the same clinical disease submitted to the same treatment. In this way, integrative molecular research in larger cohorts is imperative to better understand this devastating disease. Additional questions are also important to be considered, namely: are clinicians up to date on pharmacogenomics to apply these data in their clinical choices? Can society afford personalized medicine at all, considering the actual costs related to high throughput technologies and targeted treatments?

\section{Genomic, epigenomic and transcriptomic profiling}

Oral cancer development lies in stepwise accumulation of genomic and epigenomic changes, compromising cell division, differentiation, immune recognition, tissue invasion and metastasis [28]. DNA alterations can lead to aberrant RNA and protein, with widespread deregulation of transcription during oncogenesis. High-throughput technologies have been used to try shed light on these driving molecular mechanisms and ultimately improve the lives of OSCC patients.

Genomic changes play a significant role in tumourigenesis as well as in inter- and intratumour heterogeneity [29]. In OSCC, alterations in almost all chromosomes have been frequently reported. Nevertheless, some chromosomal regions are described in the literature as consistently altered in these tumors. Tumor progression models have been constructed, being Califano and colleagues in 1996, the first to describe a progression model for OSCC, where losses at chromosomal regions $3 p, 9 p$, and $17 p$ are considered early events in the carcinogenesis process [30]. Our group showed frequent copy number gains at 3q, 6p, 8q, 11q, $16 \mathrm{p}, 16 \mathrm{q}, 17 \mathrm{p}, 17 \mathrm{q}$ and $19 \mathrm{q}$, and copy number losses at $2 q, 3 p, 4 q, 5 q, 8 p, 9 p, 11 q$ and $18 q$ [31-33], being mapped in these regions several genes related with proliferation and cell cycle regulation. Gain in the 3q26 region, which contains the $h T E R C$ and SOX2 genes, is common in all squamous cell carcinomas and their detection could be important for early detection and for accurate prognosis of these patients [34]. We verified that gains of MYC and WISP1 genes seem to suggest higher propensity of tumors localized in the floor of the mouth [35]. However, much regarding the genomic characterization of oral cancer is still unknown, as only a few genes associated with this disease have been identified, and without implementation in routine clinical practice. The application of Next-Generation Sequencing (NGS) technologies has resulted in systematic efforts to characterize the mutational spectrum, genomic alterations, and clonal evolution of these tumors. Initial whole exome sequencing studies performed by Stransky and colleagues [36] and Agrawal and colleagues [37] identified commonly-mutated genes in HNC. This was expanded upon with the Cancer Genome Atlas (TCGA), which generated an integrated genomic annotation of molecular alterations using a comprehensive multi-platform characterization of head and neck squamous cell carcinomas to detect somatic variants [38]. Nowadays, core dysregulated pathways and actionable targets are already identified, which may justify the use of more focused and cost-effective sequencing panels that potentially yield the same information with less noise [39]. The presence of molecular heterogeneity is a problem for the genomic approaches, since tumor develop through different subpopulations of cells with different levels of genomic imbalances; therefore, the biopsy tissue analyzed might not be representative of all tumor imbalances at all the time. Moving forward, single cell sequencing will opens the door for the study of tumor heterogeneity, revealing cancer clonal evolution [40]. It might allow accurate genome-based diagnosis and consequently specific treatment for each patient with cancer.

Identification of epigenomic biomarkers has so far focused mainly on DNA methylation, since this is a wellknown epigenetic phenomenon with an established role in cancer. Growing evidence supports promoter $\mathrm{CpG}$ island hypermethylation as a bona fide mechanism for gene inactivation. New high-throughput methodologies provide information to characterize methylated sequences at single-base resolution on a genome-wide scale. Recent studies focused on identifying biomarkers of early disease detection, since DNA methylation is considered an early event in cancer process [41]. We found that WT1 gene promoter methylation is a predictor of a better prognosis and that MSH6 and GATA5 gene promoter methylation serve as predictors of a worse prognosis and a shorter survival rate in OSCC [42]. Moreover, we identified $P A X 5$ gene promoter methylation as associated with tongue tumors [42]. Epigenome-wide analysis confirmed a distinct epigenetic signature in HPV-positive HNC when compared 
to HPV-negative tumors [43]. Moreover, Pierini et al. described that traditional risk factors (tobacco and alcohol consumption) affect epigenetic modification of specific genes in laryngeal carcinomas, underlining the implication of CDKN2A and $M L H 1$ promoter methylation in invasion of lymph nodes with cancer cells [44]. DNA methylation patterns seem also to be useful to determine whether a second tumor represents a recurrence of the original malignancy or a second primary cancer [45]. Considering the stable, potential reversible nature and variable levels of epigenomic modifications in OSCC, tumor methylation profiling during treatment could provide important insights regarding the treatment efficacy, emphasizing the importance of repeatedly monitoring these patients. An attractive approach to do this monitorization is using biofluids. Several studies evaluated the presence of DNA hypermethylated in serum/plasma, saliva and exfoliated cells with promising results $[41,46]$.

Different genomic expression in HNC samples compared with normal tissue suggests that gene expression signatures can be used as a predictor of outcome in these patients. Thus, large-scale transcriptome analysis in HNC allowed the categorization of these tumors in four distinct subtypes with differences in recurrence-free survival [47, 48]. Furthermore, gene expression approaches revealed that over-expressed DNA repair genes were linked with reduced therapeutic response to radiotherapy, which can be a suitable predictor of post-radiotherapy clinical outcome [49]. Transcriptomic expression profiling confirmed the presence of molecular heterogeneity within OSCC, highlighting differences between anatomic localizations and among samples belonging to the same TNM stage [50]. Additionally, this kind of data allowed the development of prediction models in order to try identify the risk of local recurrence at surgical margins and of second primary tumors, being needed further independent studies [51].

microRNAs (miRNAs) are a group of small RNAs that specifically modulate gene expression with a significant role in tumorigenesis. Several miRNAs have been found to be up or downregulated in OSCC [52]. A molecular classification of OSCC based on 61 miRNAs with an accuracy of $93 \%$ was achieved [53]. Moreover, in this study HPV infection leads to alteration of some miRNAs, which may provide a mechanism for the distinct clinical behavior of HPV-infected tumors. The question of whether circulating miRNAs could be a biomarker for OSCC has been raised. In 2011, Wiklund and colleagues reported some candidate OSCC deregulated miRNAs with associated DNA methylation patterns, and normal miRNA expression in healthy oral epithelium and stroma [54]. These authors showed that OSCC specific miRNA and DNA methylation patterns can be detected and distinguish between patient and controls using oral rinse and saliva.
Furthermore, abnormal expression of several long noncoding RNAs (lncRNAs) were associated with tumorigenesis and metastasis in OSCC [55].

\section{Proteomic, metabolomic and lipidomic profiling}

Biochemical and biological techniques have been used to identify proteins, metabolites and lipids in OSCC.

Nowadays, functional proteomics comprise a highthroughput analysis of both basal and phosphorylated proteins active in carcinogenesis process, allowing the assessment of cellular whole protein complements in tissues or the secreted proteins in the biofluids (secretome), such as serum, plasma, urine or saliva [56]. Studies regarding OSCC have shown alteration in proteins associated to cell metabolism and structure, cellular adhesion or cell motility, signal transduction and oncoproteins [57, 58]. The proteomics tools currently available enable the analysis of a huge variety of cellular protein characteristics, namely relative protein quantities, protein cellular sub-localization and their post-translational modifications, allowing the identification of numerous candidate protein biomarkers [59]. However, it is still needed to prove their clinical value. In 2011, $\mathrm{He}$ and colleagues discriminate OSCC tumor samples from potentially malignant lesions, such as oral leukoplakia using proteomic patterns [60]. Potential salivary biomarker peptides with sensitivity up to $90 \%$ and specificity of $83 \%$ in detecting OSCC have also been proposed [61]. Moreover, classification algorithms based on differently expressed serum proteins seems to be able to distinguish patients with HNC from healthy controls with a high degree of sensitivity (83.3\%) and specificity (90\%) [62].

Metabolite profiling of tissue and biofluid samples from HNC using mass spectrometry-based metabolomic analysis has been demonstrated to be capable of discovering potential biomarkers for disease detection and treatment monitoring [63]. In serum, levels of numerous metabolites linked to the glycolytic pathway, such as glucose, were observed to be higher in oral cancer patients who had disease relapse. Similarly, the levels of some amino acids were shown to be lower in this biofluid [64]. Detection of these altered metabolites in serum of OSCC patients may contribute to early detection of recurrence [65]. In contrast to serum, the levels of metabolites associated with the glycolytic pathway seem to be lower in HNC tissue than in the non-tumor tissues. Likewise, the levels of amino acids are higher in tumor tissues [64]. Analogous results have also been previous demonstrated in colon and stomach cancer [66]. In 2015, Hu and colleagues demonstrated that the metabolic phenotypes are distinct between high and low invasive HNC cells as well as between stemlike oral cancer cells and non-stem cancer cells [67].

The alterations in lipid profile have also long been associated with cancer, since lipids play a key role in 
maintenance of cell integrity; however, few reports are available on plasma lipid profile in HNC. An inverse relationship was found between the lipid levels and occurrence of oral cancer, thus, lower plasma lipid status may be a useful indicator of neoplastic lesions [68, 69].

\section{Omics data integration}

Technological advances in high throughput microarrays, DNA sequencing, RNASeq methods and mass spectrometry approaches, together with computational and algorithmic progress, have generated progressively large amount of omics data accessible in public databases. The main problem in comparing results of data-sets generated by different research groups is the use of different platforms and also differences in sample preparation, being the correlations sometimes disappointing. The integration of omics data can yield more than the sum of the individual omics experiments, displaying the interactions that can occur among all classes of molecules in a cell, determining the cellular physiology and behavior [70], which seems to be vital to fulfill the dream of individualized cancer care and treatment.

\section{Molecular data to early diagnosis and to establish biomarkers of prognosis in OSCC}

When patients are treated within one month of onset of the symptoms, they have a 5 -year survival rate of $86 \%$, but this decreases to $47 \%$ at seven months after the beginning of the symptoms, and there is very scarce possibility of survival if the treatment occurs only after twelve months [71]. The nonspecific clinical appearance of dysplastic and early malignant lesions further highlights the need to develop objective methodologies for earlier detection [72]. Thus, taking into account that the molecular alterations may occur before phenotypic ones, molecular profiling holds great promise to predict disease progression. Simultaneously, to achieve a significant improvement in the diagnosis it is important to use the great advantage of this neoplasm, which is the accessible localization of the tumors, allowing frequent examinations, patient monitoring and easy acquisition of samples. In order to follow up the patients, biopsies do not gather all the needed requisites, since it is questionable and unpractical to get biopsies from multiples sites and/or during short periods of time, as well as from all different kinds of morphologically suspicious tissues, due to the discomfort for the patient. Thus, it seems mandatory to develop a non-invasive or minimally invasive methodology, which combined with the identification of the most appropriate prognostic molecular markers, will be very helpful for the screening of risk populations. This non-invasive methodology will also be helpful for the follow-up of the OSCC patients already undergoing treatment. In this sense, biofluids emerge as a good material to detect/analyze nucleic acid and proteins from the cancer cells, without resorting to biopsies.

\section{Conclusions}

In the present review, we focused on the contribution of genomic, epigenomic, transcriptomic, proteomic, metabolomic and lipidomic studies to the understanding and identifying of biomarkers capable of predict the clinical behavior of oral tumors. These omics approaches will also play an important role in understanding relapses at the primary site after resection, distant metastasis and the development of second primary tumors. However, many questions in this field remain to be answered. The pursuit to improve the quality of life and decrease mortality rates of the oral patients needs to be centralized on the identification of critical genes in oral carcinogenesis. This will enable to choose the treatment strategy to individualized therapy based on the molecular patient's profile. Besides the diagnosis of oral cancer, the molecular analysis will also make possible the monitoring of suspicious lesions in the higher risk populations. In this line, saliva could become in a near future a vital element in the early detection and screening of oral cancer. It will allow performing easy and non-invasive routine health screening of the high risk populations, such as individuals with HPV infection and heavy tobacco and alcohol consumption. It is also important to improve oral health care education and raise the awareness of the general population to this severe disease, which nonetheless has a favorable prognosis when early detected. Understanding the molecular biology of oral cancer is vital for search new therapies. The molecular-targeted therapies represent the most promising treatment for OSCC. EGFR-targeting agents have shown efficacy for treatment of these patients. Several studies including immunotherapeutic strategies and inhibitors of VEGFR, IGF-1R, PI3K/AKT/mTOR and MET have been conducted, being expected in a near future a shift in the management of oral cancer patients towards more personalized treatment.

\author{
Acknowledgements \\ Not applicable. \\ Funding \\ Ribeiro I.P. has a PhD fellowship (SFRH/BD/52290/2013) supported by the \\ Portuguese Foundation for Science and Technology.
}

Availability of data and materials

Not applicable.

Authors' contributions

IPR analyzed and interpreted the literature data regarding oral cancer and omics and was the major contributor in writing the manuscript. LB and FM performed the critical review of the manuscript including the clinical point of view. JBM and IMC performed the critical review of the manuscript. All authors read and approved the final manuscript. 


\section{Competing interests}

The authors declare that they have no competing interests.

\section{Consent for publication}

Not applicable.

\section{Ethics approval and consent to participate}

Not applicable.

\section{Author details}

${ }^{1}$ Cytogenetics and Genomics Laboratory, Faculty of Medicine, University of Coimbra, Polo Ciências da Saúde, Coimbra 3000-354, Portugal. ${ }^{2}$ CIMAGO Center of Investigation on Environment Genetics and Oncobiology - Faculty of Medicine, University of Coimbra, Coimbra 3000-354, Portugal. ${ }^{3}$ Maxillofacial Surgery Unit, Coimbra Hospital and University Centre, CHUC, EPE, Coimbra 3000-075, Portugal. ${ }^{4}$ Department of Dentistry, Faculty of Medicine, University of Coimbra, Coimbra 3000-075, Portugal. ${ }^{5}$ Stomatology Unit, Coimbra Hospital and University Centre, CHUC, EPE, Coimbra 3000-075, Portugal.

\section{Received: 13 October 2016 Accepted: 9 November 2016}

Published online: 23 November 2016

\section{References}

1. Forastiere A, Koch W, Trotti A, Sidransky D. Head and neck cancer. N Engl J Med. 2001;345(26):1890-900.

2. Argiris A, Karamouzis MV, Raben D, Ferris RL. Head and neck cancer. Lancet. 2008;371(9625):1695-709.

3. Kreimer AR, Clifford GM, Boyle P, Franceschi S. Human papillomavirus types in head and neck squamous cell carcinomas worldwide: a systematic review. Cancer Epidemiol Biomarkers Prev. 2005;14(2):467-75.

4. Fakhry C, Westra WH, Li S, Cmelak A, Ridge JA, Pinto H, Forastiere A, Gillison ML. Improved survival of patients with human papillomavirusâ€" positive head and neck squamous cell carcinoma in a prospective clinical trial. J Natl Cancer Inst. 2008;100(4):261-9.

5. Torre LA, Bray F, Siegel RL, Ferlay J, Lortet-Tieulent J, Jemal A. Global cancer statistics, 2012. CA Cancer J Clin. 2015:65(2):87-108.

6. Bray F, Moller B. Predicting the future burden of cancer. Nat Rev Cancer. 2006;6(1):63-74.

7. Leemans CR, Braakhuis BJ, Brakenhoff RH. The molecular biology of head and neck cancer. Nat Rev Cancer. 2011;11(1):9-22.

8. Chaturvedi AK, Anderson WF, Lortet-Tieulent J, Curado MP, Ferlay J, Franceschi S, Rosenberg PS, Bray F, Gillison ML. Worldwide trends in incidence rates for oral cavity and oropharyngeal cancers. J Clin Oncol. 2013;31(36):4550-9.

9. Simard EP, Torre LA, Jemal A. International trends in head and neck cancer incidence rates: Differences by country, sex and anatomic site. Oral Oncol. 2014;50(5):387-403.

10. Gaitan-Cepeda LA, Peniche-Becerra AG, Quezada-Rivera D. Trends in frequency and prevalence of oral cancer and oral squamous cell carcinoma in Mexicans. A 20 years retrospective study. Med Oral Patol Oral Cir Bucal. 2011;16(1):e1-5.

11. Warnakulasuriya $\mathrm{S}, \mathrm{Mak} \mathrm{V}$, Moller $\mathrm{H}$. Oral cancer survival in young people in South East England. Oral Oncol. 2007;43(10):982-6.

12. Jemal A, Bray F, Center MM, Ferlay J, Ward E, Forman D. Global cancer statistics. CA Cancer J Clin. 2011;61(2):69-90.

13. Braakhuis BJ, Brakenhoff RH, Leemans CR. Second field tumors: a new opportunity for cancer prevention? Oncologist. 2005;10(7):493-500.

14. Jo JA, Applegate BE, Park J, Shrestha S, Pande P, Gimenez-Conti IB, Brandon $J$ L. In vivo simultaneous morphological and biochemical optical imaging of oral epithelial cancer. IEEE Trans Biomed Eng. 2010;57(10):2596-9.

15. Bockmuhl U, Schluns K, Kuchler I, Petersen S, Petersen I. Genetic imbalances with impact on survival in head and neck cancer patients. Am J Pathol. 2000;157(2):369-75.

16. van der Waal I, de Bree R, Brakenhoff R, Coebergh JW. Early diagnosis in primary oral cancer: is it possible? Med Oral Patol Oral Cir Bucal. 2011;16(3):e300-5.

17. Benchekroun MT, Saintigny $P$, Thomas SM, El-Naggar AK, Papadimitrakopoulou V, Ren H, Lang W, Fan YH, Huang J, Feng L, Lee JJ, Kim ES, Hong WK, Johnson FM, Grandis JR, Mao L. Epidermal growth factor receptor expression and gene copy number in the risk of oral cancer. Cancer Prev Res (Phila). 2010;3(7):800-9.
18. Braakhuis BJM, Bloemena E, Leemans CR, Brakenhoff RH. Molecular analysis of surgical margins in head and neck cancer: more than a marginal issue. Oral Oncol. 2010;46(7):485-91.

19. Bonner JA, Harari PM, Giralt J, Azarnia N, Shin DM, Cohen RB, Jones CU, Sur R, Raben D, Jassem J, Ove R, Kies MS, Baselga J, Youssoufian H, Amellal N, Rowinsky EK, Ang KK. Radiotherapy plus cetuximab for squamous-cell carcinoma of the head and neck. N Engl J Med. 2006;354(6):567-78.

20. Vermorken JB, Mesia R, Rivera F, Remenar E, Kawecki A, Rottey S, Erfan J, Zabolotnyy D, Kienzer HR, Cupissol D, Peyrade F, Benasso M, Vynnychenko I, De Raucourt D, Bokemeyer C, Schueler A, Amellal N, Hitt R. Platinum-based chemotherapy plus cetuximab in head and neck cancer. N Engl J Med. 2008;359(11):1116-27.

21. Braig F, Voigtlaender M, Schieferdecker A, Busch CJ, Laban S, Grob T, Kriegs M, Knecht R, Bokemeyer C, Binder M: Liquid biopsy monitoring uncovers acquired RAS-mediated resistance to cetuximab in a substantial proportion of patients with head and neck squamous cell carcinoma. Oncotarget. 2016;7(28):42988-95.

22. Francisco LM, Salinas VH, Brown KE, Vanguri VK, Freeman GJ, Kuchroo VK, Sharpe AH. PD-L1 regulates the development, maintenance, and function of induced regulatory T cells. J Exp Med. 2009;206(13):3015-29.

23. Keir ME, Butte MJ, Freeman GJ, Sharpe AH: PD-1 and its ligands in tolerance and immunity. Annu Rev Immunol. 2008;26:677-704.

24. Philips GK, Atkins M. Therapeutic uses of anti-PD-1 and anti-PD-L1 antibodies. Int Immunol. 2015;27(1):39-46.

25. Tinhofer I, Budach $V$, Jöhrens K, Keilholz U. The rationale for including immune checkpoint inhibition into multimodal primary treatment concepts of head and neck cancer. Cancers Head Neck. 2016;1(1):8.

26. Ferris RL: Immunology and Immunotherapy of Head and Neck Cancer. J Clin Oncol. 2015;33(29):3293-3304.

27. Schmitz S, Ang KK, Vermorken J, Haddad R, Suarez C, Wolf GT, Hamoir M, Machiels JP. Targeted therapies for squamous cell carcinoma of the head and neck: current knowledge and future directions. Cancer Treat Rev. 2014:40(3):390-404

28. Hoffmann RR, Yurgel LS, Campos MM. Endothelins and their receptors as biological markers for oral cancer. Oral Oncol. 2010;46(9):644-7.

29. Bayani J, Selvarajah S, Maire G, Vukovic B, Al-Romaih K, Zielenska M, Squire JA. Genomic mechanisms and measurement of structural and numerical instability in cancer cells. Semin Cancer Biol. 2007;17(1):5-18.

30. Califano J, van der Riet P, Westra W, Nawroz H, Clayman G, Piantadosi S, Corio R, Lee D, Greenberg B, Koch W, Sidransky D. Genetic progression model for head and neck cancer: implications for field cancerization. Cancer Res. 1996;56(11):2488-92

31. Ribeiro IP, Marques F, Caramelo F, Pereira J, Patricio M, Prazeres $H$, Ferrao J, Juliao MJ, Castelo-Branco M, de Melo JB, Baptista IP, Carreira IM: Genetic gains and losses in oral squamous cell carcinoma: impact on clinical management. Cell Oncol (Dordr). 2014;37(1):29-39.

32. Bayerlein K, Rith T, Verdorfer I, Liehr T, Wolff E, Girod S, Gebhart E. I-FISH control of CGH-detected gain of DNA sequence copy number in oral squamous cell carcinomas (OSCC). Anticancer Res. 2000;20(1A):427-32.

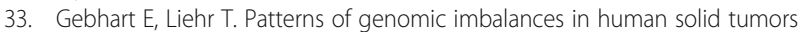
(Review). Int J Oncol. 2000;16(2):383-99.

34. Kokalj Vokac N, Cizmarevic B, Zagorac A, Zagradisnik B, Lanisnik B. An evaluation of SOX2 and hTERC gene amplifications as screening markers in oral and oropharyngeal squamous cell carcinomas. Mol Cytogenet. 2014;7(1).

35. Ribeiro IP, Marques F, Caramelo F, Ferrao J, Prazeres H, Juliao MJ, Rifi W, Savola S, de Melo JB, Baptista IP, Carreira IM: Genetic imbalances detected by multiplex ligation-dependent probe amplification in a cohort of patients with oral squamous cell carcinoma-the first step towards clinical personalized medicine. Tumour Biol. 2014;35(5):4687-95.

36. Stransky N, Egloff AM, Tward AD, Kostic AD, Cibulskis K, Sivachenko A, Kryukov GV, Lawrence MS, Sougnez C, McKenna A, Shefler E, Ramos AH, Stojanov P, Carter SL, Voet D, Cortes ML, Auclair D, Berger MF, Saksena G, Guiducci C, Onofrio RC, Parkin M, Romkes M, Weissfeld JL, Seethala RR, Wang L, Rangel-Escareno C, Fernandez-Lopez JC, Hidalgo-Miranda A, Melendez-Zajgla J, Winckler W, Ardlie K, Gabriel SB, Meyerson M, Lander ES, Getz G, Golub TR, Garraway LA, Grandis JR. The mutational landscape of head and neck squamous cell carcinoma. Science. 2011;333(6046):1157-60.

37. Agrawal N, Frederick MJ, Pickering CR, Bettegowda C, Chang K, Li RJ, Fakhry C, Xie TX, Zhang J, Wang J, Zhang N, El-Naggar AK, Jasser SA, Weinstein JN, Trevino L, Drummond JA, Muzny DM, Wu Y, Wood LD, Hruban RH, Westra WH, Koch WM, Califano JA, Gibbs RA, Sidransky D, Vogelstein B, Velculescu VE, Papadopoulos N, Wheeler DA, Kinzler KW, Myers JN. Exome sequencing of 
head and neck squamous cell carcinoma reveals inactivating mutations in NOTCH1. Science. 2011;333(6046):1154-7.

38. Cancer Genome Atlas N. Comprehensive genomic characterization of head and neck squamous cell carcinomas. Nature. 2015;517(7536):576-82.

39. Birkeland AC, Ludwig ML, Meraj TS, Brenner JC, Prince ME. The tip of the iceberg: clinical implications of genomic sequencing projects in head and neck cancer. Cancers. 2015;7(4):2094-109.

40. Navin N, Kendall J, Troge J, Andrews P, Rodgers L, Mclndoo J, Cook K, Stepansky A, Levy D, Esposito D, Muthuswamy L, Krasnitz A, McCombie WR, Hicks J, Wigler M. Tumour evolution inferred by single-cell sequencing. Nature. 2011:472(7341):90-4

41. Arantes LM, de Carvalho AC, Melendez ME, Carvalho AL, Goloni-Bertollo EM. Methylation as a biomarker for head and neck cancer. Oral Oncol. 2014;50(6):587-92.

42. Ribeiro I.P CF, Marques F, Domingues A, Mesquita M, Barroso L, Prazeres $H$, Julião M.J, Baptista I.P, Ferreira A, Melo J.B, Carreira I.M.: WT1, MSH6, GATA5 and PAX5 as epigenetic oral squamous cell carcinoma biomarkers - a short report Cellular Oncology. 2016. [Epub ahead of print]

43. Colacino JA, Dolinoy DC, Duffy SA, Sartor MA, Chepeha DB, Bradford CR, McHugh JB, Patel DA, Virani S, Walline HM, Bellile E, Terrell JE, Stoerker JA, Taylor JM, Carey TE, Wolf GT, Rozek LS. Comprehensive analysis of DNA methylation in head and neck squamous cell carcinoma indicates differences by survival and clinicopathologic characteristics. PLoS One. 2013;8(1):e54742.

44. Pierini S, Jordanov SH, Mitkova AV, Chalakov IJ, Melnicharov MB, Kunev KV, Mitev VI, Kaneva RP, Goranova TE. Promoter hypermethylation of CDKN2A, MGMT, MLH1, and DAPK genes in laryngeal squamous cell carcinoma and their associations with clinical profiles of the patients. Head Neck. 2014;36(8):1103-8.

45. Stephen JK, Symal M, Chen KM, Ghanem T, Deeb R, Shah V, Havard S, Worsham MJ. Molecular characterization of late stomal recurrence following total laryngectomy. Oncol Rep. 2011;25(3):669-76.

46. Arantes LM, de Carvalho AC, Melendez ME, Centrone CC, Gois-Filho JF Toporcov TN, Caly DN, Tajara EH, Goloni-Bertollo EM, Carvalho AL, GENCAPO. Validation of methylation markers for diagnosis of oral cavity cancer. Eur J Cancer. 2015;51(5):632-41.

47. Chung CH, Parker JS, Karaca G, Wu J, Funkhouser WK, Moore D, Butterfoss D, Xiang D, Zanation A, Yin X, Shockley WW, Weissler MC, Dressler LG, Shores CG, Yarbrough WG, Perou CM. Molecular classification of head and neck squamous cell carcinomas using patterns of gene expression. Cancer Cell. 2004;5(5):489-500.

48. Walter $\mathrm{V}$, Yin X, Wilkerson MD, Cabanski CR, Zhao N, Du Y, Ang MK, Hayward MC, Salazar AH, Hoadley KA, Fritchie K, Sailey CJ, Weissler MC, Shockley WW, Zanation AM, Hackman T, Thorne LB, Funkhouser WD, Muldrew KL, Olshan AF, Randell SH, Wright FA, Shores CG, Hayes DN. Molecular subtypes in head and neck cancer exhibit distinct patterns of chromosomal gain and loss of canonical cancer genes. PLoS One. 2013;8(2):e56823.

49. Rentoft M, Laurell G, Coates PJ, Sjostrom B, Nylander K. Gene expression profiling of archival tongue squamous cell carcinomas provides subclassification based on DNA repair genes. Int J Oncol. 2009;35(6):1321-30.

50. Severino $P$, Alvares AM, Michaluart $P$, Jr., Okamoto OK, Nunes FD, Moreira-Filho CA, Tajara EH, Head, Neck Genome Project G: Global gene expression profiling of oral cavity cancers suggests molecular heterogeneity within anatomic subsites. BMC research notes. 2008;1:113.

51. Chen C, Mendez E, Houck J, Fan W, Lohavanichbutr P, Doody D, Yueh B, Futran ND, Upton M, Farwell DG, Schwartz SM, Zhao LP. Gene expression profiling identifies genes predictive of oral squamous cell carcinoma. Cancer Epidemiol Biomarkers Prev. 2008;17(8):2152-62.

52. Sethi N, Wright A, Wood H, Rabbitts P. MicroRNAs and head and neck cancer: reviewing the first decade of research. Eur J Cancer. 2014;50(15):2619-35.

53. Lajer CB, Nielsen FC, Friis-Hansen L, Norrild B, Borup R, Garnaes E, Rossing M, Specht $L$, Therkildsen MH, Nauntofte B, Dabelsteen S, von Buchwald C. Different miRNA signatures of oral and pharyngeal squamous cell carcinomas: a prospective translational study. Br J Cancer. 2011;104(5):830-40.

54. Wiklund ED, Gao S, Hulf T, Sibbritt T, Nair S, Costea DE, Villadsen SB, Bakholdt V, Bramsen JB, Sorensen JA, Krogdahl A, Clark SJ, Kjems J. MicroRNA alterations and associated aberrant DNA methylation patterns across multiple sample types in oral squamous cell carcinoma. PLoS One. 2011;6(11):e27840.

55. Tang $H$, Wu Z, Zhang J, Su B. Salivary IncRNA as a potential marker for oral squamous cell carcinoma diagnosis. Mol Med Rep. 2013;7(3):761-6.

56. Neville BW, Day TA. Oral cancer and precancerous lesions. CA Cancer J Clin. 2002;52(4):195-215.
57. Lo WY, Lai CC, Hua CH, Tsai MH, Huang SY, Tsai CH, Tsai FJ. S100A8 is identified as a biomarker of HPV18-infected oral squamous cell carcinomas by suppression subtraction hybridization, clinical proteomics analysis, and immunohistochemistry staining. J Proteome Res. 2007:6(6):2143-51.

58. Lo WY, Tsai MH, Tsai Y, Hua CH, Tsai FJ, Huang SY, Tsai CH, Lai CC. Identification of over-expressed proteins in oral squamous cell carcinoma (OSCC) patients by clinical proteomic analysis. Clin Chim Acta. 2007;376(1-2):101-7.

59. Schaaij-Visser TB, Brakenhoff RH, Leemans CR, Heck AJ, Slijper M. Protein biomarker discovery for head and neck cancer. J Proteomics. 2010;73(10):1790-803.

60. He H, Sun G, Ping F, Cong Y. A new and preliminary three-dimensional perspective: proteomes of optimization between OSCC and OLK. Artif Cells Blood Substit Immobil Biotechnol. 2011;39(1):26-30.

61. Hu S, Arellano M, Boontheung P, Wang J, Zhou H, Jiang J, Elashoff D, Wei R, Loo JA, Wong DT. Salivary proteomics for oral cancer biomarker discovery. Clin Cancer Res. 2008;14(19):6246-52.

62. Wadsworth JT, Somers KD, Stack Jr BC, Cazares L, Malik G, Adam BL, Wright Jr GL, Semmes OJ. Identification of patients with head and neck cancer using serum protein profiles. Arch Otolaryngol Head Neck Surg. 2004;130(1):98-104.

63. Wang J, Christison TT, Misuno K, Lopez L, Huhmer AF, Huang Y, Hu S. Metabolomic profiling of anionic metabolites in head and neck cancer cells by capillary ion chromatography with Orbitrap mass spectrometry. Anal Chem. 2014;86(10):5116-24.

64. Yonezawa K, Nishiumi S, Kitamoto-Matsuda J, Fujita T, Morimoto K, Yamashita D, Saito M, Otsuki N, Irino Y, Shinohara M, Yoshida M, Nibu K. Serum and tissue metabolomics of head and neck cancer. Cancer Genomics Proteomics. 2013;10(5):233-8.

65. Tiziani S, Lopes V, Gunther UL. Early stage diagnosis of oral cancer using $1 \mathrm{H}$ NMR-based metabolomics. Neoplasia. 2009:11(3):269-76. 264p following 269.

66. Hirayama A, Kami K, Sugimoto M, Sugawara M, Toki N, Onozuka H, Kinoshita T, Saito N, Ochiai A, Tomita M, Esumi H, Soga T. Quantitative metabolome profiling of colon and stomach cancer microenvironment by capillary electrophoresis time-of-flight mass spectrometry. Cancer Res. 2009;69(11):4918-25.

67. Hu S, Wang J, Ji EH, Christison T, Lopez L, Huang Y. Targeted metabolomic analysis of head and neck cancer cells using high performance lon chromatography coupled with a Q exactive HF mass spectrometer. Anal Chem. 2015;87(12):6371-9.

68. Chawda JG, Jain SS, Patel HR, Chaduvula N, Patel K. The relationship between serum lipid levels and the risk of oral cancer. Indian J Med Paediatr Oncol. 2011;32(1):34-7.

69. Patel PS, Shah MH, Jha FP, Raval GN, Rawal RM, Patel MM, Patel JB, Patel DD. Alterations in plasma lipid profile patterns in head and neck cancer and oral precancerous conditions. Indian J Cancer. 2004:41(1):25-31.

70. Buescher JM, Driggers EM: Integration of omics: more than the sum of its parts. Cancer \& metabolism. 2016:4:4

71. Bhandary S, Bhandary P. Cancer of the oral cavity- a growing concern in the Micronesia: a case report from the Marshall Islands. Pac Health Dialog. 2003;10(1):76-8.

72. Scott IS, Odell E, Chatrath P, Morris LS, Davies RJ, Vowler SL, Laskey RA, Coleman N. A minimally invasive immunocytochemical approach to early detection of oral squamous cell carcinoma and dysplasia. Br J Cancer. 2006;94(8):1170-5. 